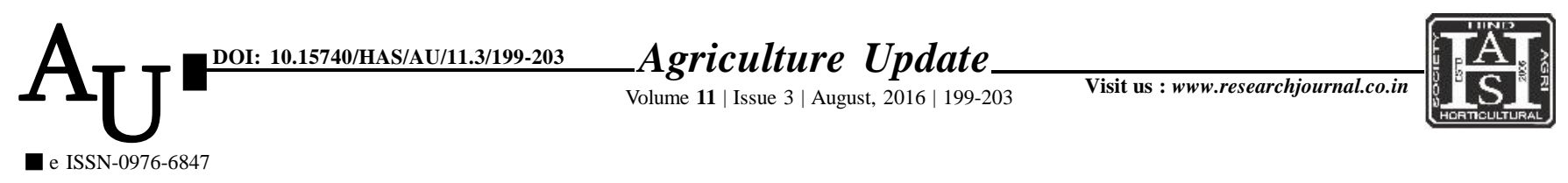

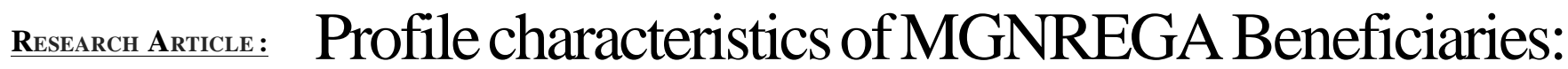 A study in Chhota Udaipur district of Gujarat
}

\author{
GORDHAN SINGH BHATI, KESHA RAM AND SUNIL R. PATEL
}

Article Chronicle:
Received :
25.04.2016;
Revised :
07.06.2016;
Accepted :
20.06.2016

KEY Words : MGNREGA,

Beneficiaries, Attitude

Author for correspondence :

\section{GORDHAN SINGH}

\section{BHATI}

Department of Extension Education, B.A. College of Agriculture, Anand Agricultural University, ANAND (GUJARAT) INDIA Email: gsbhati89@gmail. com

See end of the article for authors' affiliations
SUMMARY : MGNREGA is one of key component of the antipoverty strategy of Government of India counting as largest employment generating programme in world ensuring right to work in a country with a population of over a billion which is demand driven programme. It focuses mainly on rural most area where people have somewhat different surrounding that makes their profile. So, it is important to study such profile characteristics that helps to get deeper understanding about this programme. Present study was conducted in Chottaudepur district using multistage purposive random sampling. 100 MGNREGA beneficiaries both male and female were selected randomly. Data were collected using a pre-tested interview schedule. The findings revealed that majority of the beneficiaries were from middle age group, were illiterate or had up to secondary level of education, had large and joint type of family and were from SC and ST category. Membership in one or more than one social organization, Rs. 48,001 to Rs. 1,02,000 of annual income and were landless or had marginal size of land holding. MGNREGA alone or MGNREGA in addition to labour, agriculture labour and animal husbandry was the major occupation. Significant reduction in migration habit was observed after implementation of MGNREGA. Moderately favourable to less favourable attitude towards agriculture as occupation and had medium to low economic motivation.

How to cite this article : Bhati, Gordhan Singh, Ram, Kesha and Patel, Sunil R. (2016). Profile characteristics of MGNREGA Beneficiaries: A study in Chhota Udaipur district of Gujarat. Agric. Update, 11(3): 199-203, DOI : 10.15740/HAS/AU/11.3/199-203. 